\title{
IN SITU DRIFTS/MS STUDIES ON THE INTERACTION OF METHANOL AND ETHYL ACETATE OVER MG-LA CATALYST
}

\author{
Adão S. Gonçalves ${ }^{a, b}$, Cristiane A. Henriques ${ }^{a, b, *,(i)}$ and Deborah V. Cesar ${ }^{b}$ \\ aNúcleo de Catálise, Universidade Federal do Rio de Janeiro, 21941-914 Rio de Janeiro - RJ, Brasil \\ bDepartamento de Química Analítica, Universidade do Estado do Rio de Janeiro, 20550-900 Rio de Janeiro - RJ, Brasil
}

Recebido em 31/03/2020; aceito em 16/06/2020; publicado na web em 03/08/2020

\begin{abstract}
The surface intermediates formed on the Mg-La catalyst (molar ratio 1:1) were studied through temperature-programmed desorption (TPD) and diffuse reflectance infrared Fourier transform spectroscopy coupled to mass spectrometry (DRIFTS-MS) using methanol $(\mathrm{MeOH})$ and ethyl acetate (EA) as probe molecules. TPD results showed that the products formed from adsorbed $\mathrm{MeOH}$ were hydrogen and formaldehyde, whereas EA produced hydrogen, ethanol, and acetone. DRIFTS-MS of a MeOH and EA mixture results showed that methanol adsorbs as methoxy species on the catalyst surface, and EA adsorbs through the oxygen of carbonyl groups forming ethoxy and acetate species. The reaction of the adsorbed intermediate species resulted in the formation of methane, $\mathrm{CO}_{2}$ gas phase, ethanol, and methyl acetate. Also, methanol adsorbed preferentially on the basic site and EA in a dissociative form. Surface intermediates identification allowed to confirm that the Eley-Rideal type mechanism was predominant on the catalyst surface studied.
\end{abstract}

Keywords: DRIFTS analyses; Mg-La catalyst; surface characterization; ethyl acetate; methanol.

\section{INTRODUCTION}

Transesterification reactions play a significant role in many areas of the chemical industry, and in the last years, they have been received particular attention due to biodiesel production. These reactions can be promoted by acid or basic catalysts in both homogeneous and heterogeneous medium. In the conventional process of biodiesel production, the homogeneous basic catalysts (sodium or potassium hydroxides or alkoxides) are preferred because the reaction occurs at higher reaction rates under mild conditions. ${ }^{1,2}$ However, the homogeneous catalytic systems have some technical drawbacks, such as the difficulty for removal of the basic catalysts after the reaction, the large amount of wastewater produced to separate the catalyst and clean the products, and the occurrence of saponification reaction and emulsification. Thus, the replacement of the homogeneous catalysts for heterogeneous ones is a promising and cleaner alternative due to the reduction of the number of toxic wastes and corrosion risks, easy handling and separation, catalysts reuse, and possible use of fixed bed reactors. ${ }^{3,4}$

A variety of catalysts is evaluated for applying on transesterification reactions, especially those with basic properties based on alkaline and alkaline-earth metal oxides, salts supported on alumina, zeolites, and hydrotalcite. ${ }^{5}$ According to Islam and coworkers, ${ }^{5}$ the performance is dependent on the physicochemical of the catalyst properties, such as strong acid/base sites, high surface area, and porosity.

$\mathrm{MgO}$-based mixed oxides derived from the hydrotalcite-type structure have shown good results as catalysts for transesterification reactions. Among them, $\mathrm{MgO} / \mathrm{Al}_{2} \mathrm{O}_{3},{ }^{6,7} \mathrm{MgO} / \mathrm{La}_{2} \mathrm{O}_{3}{ }^{8,9}$ and $\mathrm{MgO} / \mathrm{La}_{2} \mathrm{O}_{3} / \mathrm{Al}_{2} \mathrm{O}_{3},{ }^{10}$ whose formulations should favor the presence of basic Brønsted sites, ${ }^{6,11,12}$ have stood out due to its high activity and improved yield and selectivity to fatty acid alkyl esters. Mg-La catalysts have received particular attention since lanthanum increases $\mathrm{MgO}$ activity, stability and provides a material easy to regenerate in the transesterification reaction of refined sunflower oil with methanol, with a variation of $5 \%$ in the conversion approximately. ${ }^{9}$ In a previous study, Mg-La based catalysts showed promising performance concerning the production of methyl esters via transesterification reaction. ${ }^{3}$ The evaluation of the influence of the chemical composition ( $\mathrm{Mg} / \mathrm{La}$ molar ratio) indicated that solids with $\mathrm{Mg} / \mathrm{La}$ molar ratio equal to 9:1 and 1:1 produce the highest fatty acid methyl esters (FAME) yields. These results correlated well with the basic site density and the presence of super basic sites. ${ }^{3}$ The comparison of these catalysts $(\mathrm{Mg} / \mathrm{La}$ molar ratio of $9: 1$ and $1: 1$ ), with $\mathrm{Al} / \mathrm{La}$ catalysts with molar ratios 9:1 and $1: 1$ in the transesterification of soybean oil and methanol, showed that all catalysts had a similar performance at $200{ }^{\circ} \mathrm{C}$. At $130{ }^{\circ} \mathrm{C}$, both the $\mathrm{Mg} / \mathrm{La}$ catalysts 9:1 and 1:1 had higher yields than the corresponding $\mathrm{Al} / \mathrm{La}$ samples. However, the authors could not establish a relationship between the catalytic activity and the surface properties of the catalysts.

Thus, fundamental studies using probe molecules are essential to get a better understanding of the catalyst properties. In general, the literature presents studies using infrared spectroscopy analyses for $\mathrm{MgO}$ catalyst, ${ }^{11,13,14}$ which show that methanol adsorbs both in the molecular and the dissociative form on $\mathrm{MgO}$. The dissociation occurs by breaking the $\mathrm{OH}$ bond of the alcohol and forms methoxy species linked to an $\mathrm{Mg}^{2+}$ ion (methoxy type I species), or two ions $\mathrm{Mg}^{2+}$ (methoxy type II species). The adsorption of methanol on $\mathrm{Mg}-\mathrm{Al}$ hydrotalcite catalysts have shown that methanol adsorption occurs in the same manner as described for $\mathrm{MgO} .^{7,14-16}$

Therefore, although the adsorption of methanol on basic surfaces has been well investigated using infrared spectroscopy, ${ }^{11,12,14}$ similar studies concerning an ester molecule are less common, particularly over Mg-La catalysts.

In this work, in situ diffuse reflectance infrared Fourier transform spectroscopy coupled to mass spectrometry DRIFTS-MS was used to investigate the interaction of methanol $(\mathrm{MeOH})$ and ethyl acetate (EA, chosen as a model ester) with Mg-La catalyst with a molar ratio of 1:1 trying to provide some insights on the reaction route. The catalyst with a nominal metal proportion equal to $1: 1$ was chosen to avoid a majority influence of one of the metals ( $\mathrm{Mg}$ or $\mathrm{La})$. 


\section{EXPERIMENTAL}

\section{Catalyst preparation}

The precursor material was synthesized by coprecipitation, at room temperature, using an aqueous solution of metallic cations (solution $\mathrm{A}$ ) and a basic solution (solution $\mathrm{B}$ ) under vigorous stirring. Solution A, containing $\mathrm{Mg}\left(\mathrm{NO}_{3}\right)_{2} \cdot 4 \mathrm{H}_{2} \mathrm{O}$ and $\mathrm{La}\left(\mathrm{NO}_{3}\right)_{3} \cdot 9 \mathrm{H}_{2} \mathrm{O}$ dissolved in distilled water with $1.4 \mathrm{~mol} \mathrm{~L}^{-1}$ in $(\mathrm{Mg}+\mathrm{La})$ and $\mathrm{Mg} / \mathrm{La}$ molar ratio equal to $1: 1$ was slowly dropped $\left(60 \mathrm{~mL} \mathrm{~h}^{-1}\right)$ into solution $\mathrm{B}$ containing $\left(\mathrm{NH}_{4}\right)_{2} \mathrm{CO}_{3}\left(0.94 \mathrm{~mol} \mathrm{~L}^{-1}\right)$. The $\mathrm{pH}$ of the suspension was kept at 11 by the addition of $\mathrm{NH}_{4} \mathrm{OH}(30 \%)$. Then, the suspension was heated at $65{ }^{\circ} \mathrm{C}$ under magnetic stirring and maintained at this temperature for $3 \mathrm{~h}$. After it was filtered and the solid was washed with hot deionized water $\left(90^{\circ} \mathrm{C}\right)$ until $\mathrm{pH} 7$ and then dried at $100{ }^{\circ} \mathrm{C}$ for $12 \mathrm{~h}$. The sample was named $1 \mathrm{Mg} 1 \mathrm{LaD}$, where $\mathbf{D}$ means dry.

The catalyst was obtained by thermal treatment of the precursor under air flowing $\left(50 \mathrm{~mL} \mathrm{~min}\right.$ ) from room temperature to $450{ }^{\circ} \mathrm{C}$, at a $5{ }^{\circ} \mathrm{C} \mathrm{min} \mathrm{m}^{-1}$ heating rate, and kept at this temperature for $8 \mathrm{~h}$, with steps of $1 \mathrm{~h}$ at 150 and $300{ }^{\circ} \mathrm{C} .{ }^{3}$ It was named $1 \mathrm{Mg} 1 \mathrm{LaC}$, where $\mathbf{C}$ means calcined.

\section{Characterization of the catalyst}

The chemical composition of the catalyst was determined by X-ray fluorescence spectrometry (XRF), using a RIGAKU spectrometer, model RIX 3100, controlled by software Rix 3100, equipped with $\mathrm{X}$-ray tube of Rhodium (Rh). The analysis was conducted without sample dilution. The specific area was measured in a Micromeritics ASAP2020 by $\mathrm{N}_{2}$ adsorption at $196^{\circ} \mathrm{C}$, applying the BET method. Before analysis, the samples were pretreated under vacuum $\left(5 \times 10^{-3}\right.$ torr $)$ at $300{ }^{\circ} \mathrm{C}$ overnight.

In order to determine the phase present in both dried and calcined samples, X-ray powder diffractograms were obtained in a Miniflex/ Rigaku diffractometer equipped with a graphite monochromator using $\mathrm{Cu} \mathrm{K} \alpha$ radiation, $30 \mathrm{kV}$ and $15 \mathrm{~mA}$. The diffractograms were registered in Bragg angles $(2 \theta)$ in the range of $10^{\circ}<2 \theta<80^{\circ}$ with steps of $0.05^{\circ}$ at $2 \mathrm{~s} / \mathrm{step}$. The identification of crystalline phases present was made using MDI Jade 5 software (Materials Data Inc), using the data files of the International Center for Diffraction Data ICDD PDF-2 Database.

\section{TPD analyses}

Temperature Programmed Desorption (TPD) was performed in a home-made instrument equipped with an online quadrupole mass spectrometer (Balzers QMS 422). The samples ( 100 mg) were pretreated at $200{ }^{\circ} \mathrm{C}$ for $1 \mathrm{~h}$ under flowing $\mathrm{He}\left(60 \mathrm{~mL} \mathrm{~min}^{-1}\right)$ and then cooled down to $25^{\circ} \mathrm{C}$. The probe molecule (methanol, ethyl acetate, or a mixture of methanol and ethyl acetate $1: 1 \mathrm{~mol} / \mathrm{mol}$ ) was chemisorbed at room temperature by flowing $\mathrm{He}\left(60 \mathrm{~mL} \mathrm{~min}^{-1}\right)$, for $30 \mathrm{~min}$, through a saturator (kept at $0^{\circ} \mathrm{C}$ ) in which it was contained. Afterward, the sample was purged for $1 \mathrm{~h}$ in He flow $\left(60 \mathrm{~mL} \mathrm{~min}^{-1}\right)$ to remove any physically adsorbed species, and then the temperature was increased at a heating rate of $10{ }^{\circ} \mathrm{C} \mathrm{min}^{-1}$ up to $500{ }^{\circ} \mathrm{C}$, remaining at this temperature for $3 \mathrm{~h}$. The desorbing species were continuously monitored by their characteristic mass fragments $(\mathrm{m} / \mathrm{z})$ : $2\left(\mathrm{H}_{2}\right) ; 14$ (methane); $17\left(\mathrm{H}_{2} \mathrm{O}\right) ; 26$ (ethylene); 30 (formaldehyde); 31 (methanol); $44\left(\mathrm{CO}_{2}\right) ; 46$ (ethanol); 58 (acetone); 61 (ethyl acetate). The fragment $(\mathrm{m} / \mathrm{z})=28$ was also included in some figure profiles to distinguish methanol and formaldehyde, once both substances produce this fragment in common, as shown in Table 1. The intensities were corrected to account for the contributions of different compounds. In the experiment with the methanol and ethyl acetate mixture, the molar ratio of the reactants in the liquid mixture in the saturator at $0{ }^{\circ} \mathrm{C}$ was calculated using the software HYSYS Process v.2.2, which ensured the molar ratio of $1: 1$ in the gas fed. Thus, the liquid mixture contained $41 \%$ of methanol and $59 \%$ of ethyl acetate. The same procedure was applied for DRIFTS experiments.

\section{In situ DRIFTS-MS}

The Diffuse Reflectance Infrared Fourier Transform Spectroscopy coupled with Mass Spectrometry (DRIFTS-MS) analysis was performed in a Thermo Nicolet spectrometer, model Nexus 470, equipped with an MCT detector and a high-temperature chamber (Harrick) with $\mathrm{ZnSe}$ windows. Spectra were acquired between $650 \mathrm{~cm}^{1}-4000 \mathrm{~cm}^{-1}$ with a resolution of $4 \mathrm{~cm}^{-1}$ and 150 scans. The outlet line of the high-temperature chamber was coupled to a Pfeiffer mass spectrometer model QMS Prisma, with CH-TRON detector. For the experiment, $40 \mathrm{mg}$ of the $1 \mathrm{Mg} 1 \mathrm{LaC}$ catalyst was pre-treated under He flow $\left(40 \mathrm{~mL} \mathrm{~min}^{-1}\right)$ from room temperature to $200{ }^{\circ} \mathrm{C}$, at a heating rate of $10{ }^{\circ} \mathrm{C} \mathrm{min}^{-1}$, and kept at $200{ }^{\circ} \mathrm{C}$ for $1 \mathrm{~h}$. Then, the sample was cooled down to $30^{\circ} \mathrm{C}$, and a stream of He saturated with methanol/ethyl acetate mixture (1:1 molar basis) was introduced into the chamber, which was maintained at $30{ }^{\circ} \mathrm{C}$ for $15 \mathrm{~min}$. After removing the reversible adsorbed probe molecule using a flow of $\mathrm{He}\left(40 \mathrm{~mL} \mathrm{~min}^{-1}\right)$ for $1 \mathrm{~h}$, the catalyst was heated up to different temperatures $\left(50^{\circ} \mathrm{C}, 100^{\circ} \mathrm{C}, 150{ }^{\circ} \mathrm{C}, 200^{\circ} \mathrm{C}\right.$, $250{ }^{\circ} \mathrm{C}, 300{ }^{\circ} \mathrm{C}, 350{ }^{\circ} \mathrm{C}, 400{ }^{\circ} \mathrm{C}, 450{ }^{\circ} \mathrm{C}, 500{ }^{\circ} \mathrm{C}$ ) under He flow $\left(40 \mathrm{~mL} \mathrm{~min}{ }^{-1}\right)$, remaining in temperature until the IR spectrum is collected. Spectra were acquired at the end of the probe molecule adsorption step and each of the temperature stages. The spectra of the sample after pre-treatment under He were used as background. The following selected mass spectroscopy signals $(\mathrm{m} / \mathrm{z})$ were monitored continuously with time and temperature: $2\left(\mathrm{H}_{2}\right) ; 14$ (methane);

Table 1. $\mathrm{m} / \mathrm{z}$ fragments of the products formed during Methanol and Ethyl Acetate TPD-MS and DRIFTS-MS analyses

\begin{tabular}{lll}
\hline & Product & $\mathrm{m} / \mathrm{z}(\%)$ \\
\hline \multirow{3}{*}{ Methanol } & Hydrogen & $2(100 \%)$ \\
& Formaldehyde & $13(1 \%) ; 14(1.3 \%) ; 18(2.6 \%) ; 28(26.8 \%) ; 29(100 \%) ; 30(78.6 \%) ; 31(1.4 \%)$ \\
& Methanol & $14(1.7 \%) ; 15(12.4 \%) ; 28(4.6 \%) ; 29(44.6 \%) ; 30(6.5 \%) ; 31(100 \%) ; 32(74.4 \%) ; 33(1.2 \%)$ \\
\hline & Methane & $16(100 \%) ; 15(85.8 \%) ; 14(15.6 \%)$ \\
& & $14(1.4 \%) ; 15(3.4 \%) ; 19(2.3 \%) ; 26(4.9 \%) ; 27(17.7 \%) ; 28(4.2 \%) ; 29(12 \%) ; 30(5 \%) ; 31(100 \%) ; 32(1.4 \%) ; 41(1 \%) ;$ \\
& Ethanol & $42(3.4 \%) ; 43(9.9 \%) ; 44(1 \%) ; 45(57.3 \%) ; 46(24.6 \%)$ \\
Ethyl Acetate & & $14(2.9 \%) ; 15(23.1 \%) ; 26(3.5 \%) ; 27(5.7 \%) ; 28(1.2 \%) ; 29(3.1 \%) ; 37(1.8 \%) ; 38(2.2 \%) ; 39(4.2 \%) ; 40(1 \%) ; 41(2 \%) ;$ \\
& Acetone & $42(9.1 \%) ; 43(100 \%) ; 44(3.4 \%) ; 57(1.7 \%) ; 58(63.8 \%) ; 59(3.1 \%)$ \\
& & $18(100 \%) ; 17(23 \%) ; 16(1,6 \%)$ \\
& $\mathrm{H}_{2} \mathrm{O}$ & $44(100 \%) ; 28(11 \%) ; 16(8,5 \%)$ \\
& $\mathrm{CO}_{2}$ &
\end{tabular}


$18\left(\mathrm{H}_{2} \mathrm{O}\right) ; 26$ (ethylene); 30 (formaldehyde); 31 (methanol); $44\left(\mathrm{CO}_{2}\right) ;$ 46 (ethanol); 58 (acetone); 61 (ethyl acetate).

\section{RESULTS AND DISCUSSION}

\section{Characterization of the catalyst}

The $\mathrm{Mg} / \mathrm{La}$ molar ratio of the catalyst, measured by XRF, was equal to $0.63\left(13.38 \% \mathrm{MgO}\right.$ and $\left.86.62 \% \mathrm{La}_{2} \mathrm{O}_{3}\right)$, which is lower than the corresponding nominal values in the synthesis gel $(\mathrm{Mg} / \mathrm{La}=1.0)$. This fact indicates that the incorporation of $\mathrm{Mg}$ was lower than the expected, probably due to the higher solubility of $\mathrm{Mg}$ compounds at the $\mathrm{pH}$ of the synthesis. A similar trend was reported in the literature for $\mathrm{Mg}-\mathrm{La}$ and $\mathrm{La}-\mathrm{Mg}-\mathrm{Al}$ catalysts prepared by coprecipitation. ${ }^{3,8}$ However, only Simanjuntak et al. ${ }^{17}$ tried to explain this trend suggesting the occurrence of the solubilization of $\mathrm{Mg}$ compounds during the precipitation process.

The BET specific area of the catalyst was $38 \mathrm{~m}^{2} \mathrm{~g}^{-1}$, which is in the range of those reported in the literature for Mg-La-based catalysts prepared using similar methodology with an equivalent composition. ${ }^{3,9}$

The X-ray diffractogram of the catalyst precursor $1 \mathrm{Mg} 1 \mathrm{LaD}$, shown in Figure 1, indicated that a low-crystallinity hydrated lanthanum oxy-carbonate, $\mathrm{La}_{2} \mathrm{O}\left(\mathrm{CO}_{3}\right)_{2} \cdot \mathrm{H}_{2} \mathrm{O}$ (JCPDS 28-0512), was the single-phase identified. After calcination at $450{ }^{\circ} \mathrm{C}$, the XRD pattern of the sample exhibited broad diffraction peaks, and lanthanum di-oxycarbonate phase, $\mathrm{La}_{2} \mathrm{CO}_{5}$, (JPCDS 23-0320) was identified for $1 \mathrm{Mg} 1 \mathrm{LaC}$ (Figure 1). The formation of the $\mathrm{MgO}$ phase was not evident, but it cannot be discarded, once broad peaks in the range of $2 \theta=35-80^{\circ}$ should contain the contribution of $\mathrm{MgO}$ phase $(2 \theta=36$, $43,62,74$ and $79^{\circ}$; JCPDS 75-1525) with low crystallinity.

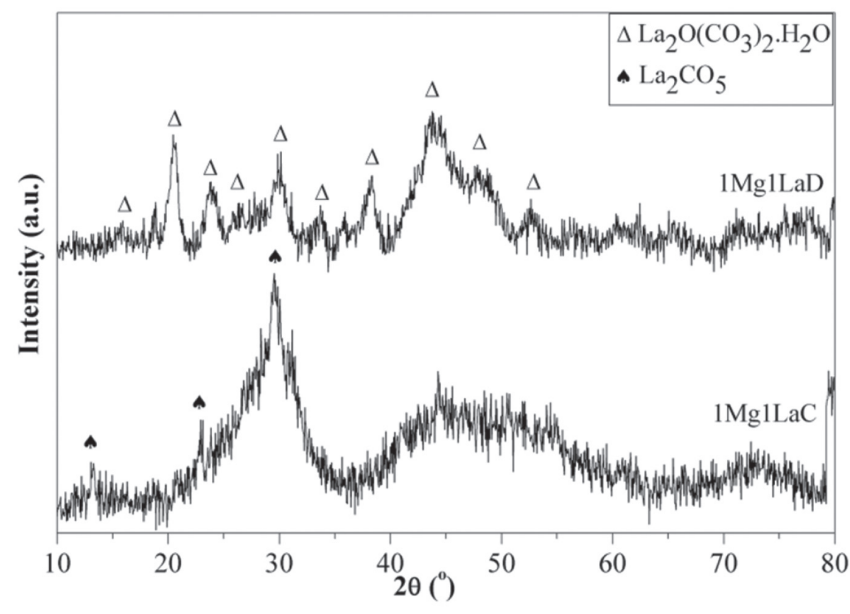

Figure 1. X-ray diffractograms of the samples $1 \mathrm{Mg} 1 \mathrm{LaD}$ and $1 \mathrm{Mg} 1 \mathrm{LaC}$

This result suggests that under the conditions employed for calcination, the decomposition of the carbonate did not occur. However, it is noteworthy that even in the presence of these carbonate species, Mg-La catalysts had shown activity for the transesterification reaction in a previous study. ${ }^{3}$ Although there are authors that report the presence of brucite as one of the phases identified in the $\mathrm{Mg}-\mathrm{La}$ precursors, ${ }^{8}$ brucite was not identified in the $1 \mathrm{Mg} 1 \mathrm{LD}$, probably due to the lower Mg-content in the synthesis gel and the methodology used for the synthesis. Besides, as to the nature of the sites present on the catalyst, the results of Santorio et al. ${ }^{3}$ allowed us to infer the presence of both basic and acid sites. These authors evaluated a series of Mg-La catalyst (nominal Mg/La molar ratios 9/1; 1/1; 1/9), prepared by the same method used in the present work, in the catalytic conversion of 2-propanol. They observed the presence of propene along with acetone as reaction products. The mechanism involved in the formation of these compounds indicates the presence of both acid and basic sites with intermediate strength. ${ }^{3}$

\section{Temperature-programmed desorption}

Temperature-programmed desorption of methanol and ethyl acetate (solely or in a mixture) was performed to evaluate the interaction of these reactants with the surface of $\mathrm{Mg}$-La catalyst and to identify the products desorbed.

Figure 2 shows the TPD profiles after adsorption of methanol at room temperature. The desorption of molecularly adsorbed methanol (unreacted methanol, $\mathrm{m} / \mathrm{z}=31$ ) was observed between $35^{\circ} \mathrm{C}$ and $500{ }^{\circ} \mathrm{C}$, with two peaks: at $110{ }^{\circ} \mathrm{C}$, related to methanol weakly adsorbed, and at $270{ }^{\circ} \mathrm{C}$, corresponding to methanol with strong interaction with catalysts surface. In the same range of temperature $\left(35^{\circ} \mathrm{C}-500{ }^{\circ} \mathrm{C}\right)$, the signal of the fragment $\mathrm{m} / \mathrm{z}=30$ is related to methanol contribution until approximately $390{ }^{\circ} \mathrm{C}$. Above $370{ }^{\circ} \mathrm{C}$, the formation of $\mathrm{H}_{2}$ and formaldehyde was detected and associated with the fragment $\mathrm{m} / \mathrm{z}=2, \mathrm{~m} / \mathrm{z}=28$, and 30 , respectively.

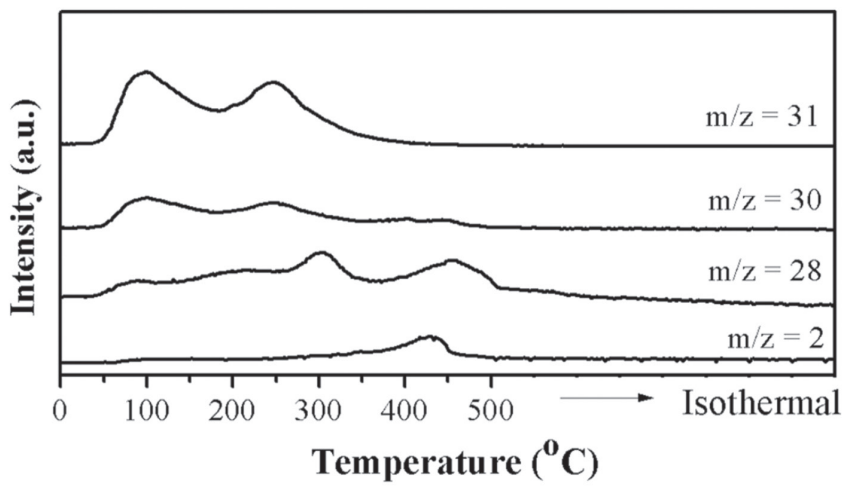

Figure 2. Temperature-programmed desorption profiles obtained after methanol adsorption at room temperature $(\mathrm{m} / \mathrm{z}$ : hydrogen $=2$; formaldehyde $=30$, $28 ;$ methanol $=31$

TPD results are following alcohol adsorption behavior, where primary alcohols adsorb on the surface of metal oxides without dissociation or through the scission of the $\mathrm{OH}$ bond as mono- (Type I) or bidentate (Type II) alkoxides. ${ }^{11}$ These methoxy species can be desorbed as molecular methanol or can react at higher temperatures $\left(\mathrm{T}>300{ }^{\circ} \mathrm{C}\right.$ ), via dehydrogenation reaction (equation 1), producing formaldehyde and hydrogen. ${ }^{18}$

$$
\mathrm{CH}_{3} \mathrm{OH} \rightarrow \mathrm{CH}_{2} \mathrm{O}+\mathrm{H}_{2}
$$

TPD profiles after adsorption of ethyl acetate at room temperature (Figure 3) show a low-intensity signal associated with the desorption of molecular ethyl acetate at about $100{ }^{\circ} \mathrm{C}(\mathrm{m} / \mathrm{z}=61)$, along with the desorption of other species. According to the literature, ethyl acetate adsorbs in a dissociative form on the catalyst surface and desorbs forming ethanol, acetone, ethylene, and diethyl ether; further, the ethanol adsorbed can produce acetone, methanol, methane, and hydrogen. ${ }^{19,20}$ In our results, hydrogen $(\mathrm{m} / \mathrm{z}=2)$, ethanol $(\mathrm{m} / \mathrm{z}=46)$ and acetone $(\mathrm{m} / \mathrm{z}=58)$ were formed in the range of $50-500{ }^{\circ} \mathrm{C}$, which confirm that ethyl acetate adsorbs in a dissociative form on the catalyst surface forming ethoxy species that desorbed as ethanol. The first peak at $130{ }^{\circ} \mathrm{C}$ is due to ethanol produced from weakly adsorbed ethoxy, while the second $\left(500{ }^{\circ} \mathrm{C}\right)$ is related to ethoxy species with stronger interaction with the surface. Above $300^{\circ} \mathrm{C}$, the TPD profile 


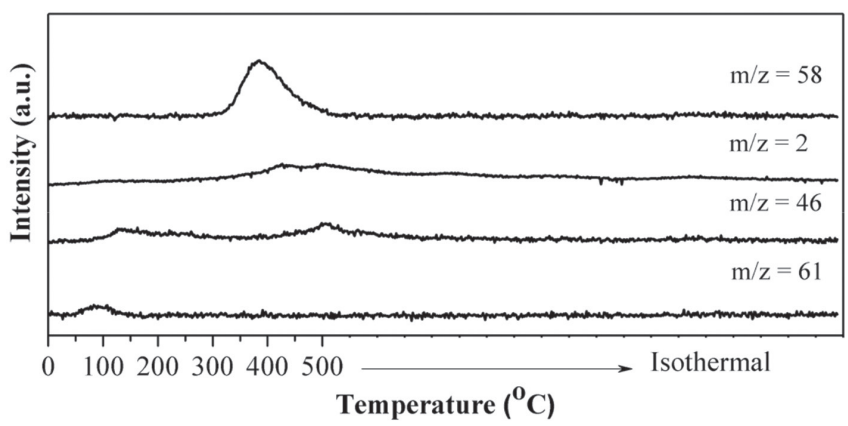

Figure 3. Temperature-programmed desorption profiles obtained after ethyl acetate adsorption at room temperature $(\mathrm{m} / \mathrm{z}$ : hydrogen $=2$; ethanol $=46$; acetone $=58$, ethyl acetate $=61$ )

also showed the formation of acetone $(\mathrm{m} / \mathrm{z}=58)$, with a maximum at $380{ }^{\circ} \mathrm{C}$. There are two hypotheses to acetone formation, the first deriving from the decomposition of ethyl acetate that also forms $\mathrm{CO}_{2}$ and $\mathrm{H}_{2} \mathrm{O}$ as by-products (Figure $1 \mathrm{~S}$, supplementary material), according to equation $2 .^{21}$

$$
2 \mathrm{H}_{3} \mathrm{C}-\mathrm{CH}_{2}-\mathrm{OOC}-\mathrm{CH}_{3} \rightarrow \mathrm{CH}_{3} \mathrm{COCH}_{3}+\mathrm{CO}_{2}+\mathrm{H}_{2} \mathrm{O}
$$

Another possibility to form acetone is from acetate adsorbed on the surface: ${ }^{20}$

$$
2 \mathrm{CH}_{3} \mathrm{COO}_{\text {ads }}^{-} \rightarrow \mathrm{CH}_{3} \mathrm{COCH}_{3}+\mathrm{CO}_{2}+\mathrm{O}_{(\mathrm{s})}
$$

Figure 4 shows the TPD profiles after the adsorption of the methanol and ethyl acetate mixture $(1: 1 \mathrm{~mol} / \mathrm{mol})$ at room temperature. Methanol molecularly adsorbed $(\mathrm{m} / \mathrm{z}=31)$ was released in the range of $50{ }^{\circ} \mathrm{C}-400{ }^{\circ} \mathrm{C}$, similar to that was observed for methanol solely (Figure 2), with a maximum of temperature at $100{ }^{\circ} \mathrm{C}$ (methanol weakly adsorbed) and at $240{ }^{\circ} \mathrm{C}$ (methanol strongly adsorbed).

The desorption of hydrogen $(\mathrm{m} / \mathrm{z}=2)$ was detected between $200{ }^{\circ} \mathrm{C}$ and $500{ }^{\circ} \mathrm{C}$, with a maximum at $320{ }^{\circ} \mathrm{C}$, followed by formaldehyde formation $(\mathrm{m} / \mathrm{z}=28)$, which was used to confirm its

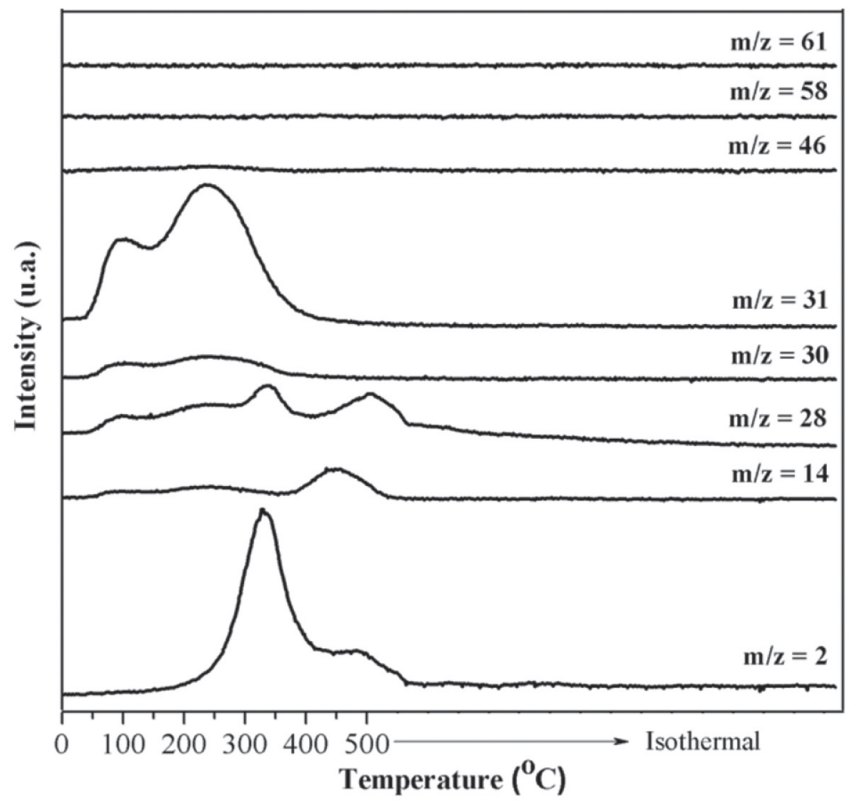

Figure 4. Temperature-programmed desorption profiles obtained after adsorption of the mixture methanol/ethyl acetate $(1 / 1 \mathrm{~mol} / \mathrm{mol})$ at room temperature. $(\mathrm{m} / \mathrm{z}$ : hydrogen $=2$; methane $=14$; formaldehyde $=30,28$; methanol $=31 ;$ ethanol $=46)$ formation once the fragment $\mathrm{m} / \mathrm{z}=30$ are also related to methanol contribution.

Methane formation appears between $380{ }^{\circ} \mathrm{C}$ and $500{ }^{\circ} \mathrm{C}$, with a maximum at $430{ }^{\circ} \mathrm{C}$, and it could be due to the acetate species decomposition, ${ }^{21}$ as follows:

$$
\mathrm{CH}_{3} \mathrm{COO}^{-}{ }_{\mathrm{ads}}^{-}+\mathrm{OH}_{(\mathrm{s})} \rightarrow \mathrm{CH}_{4}+\mathrm{CO}_{2}+\mathrm{O}^{2-}{ }_{(\mathrm{s})}
$$

However, the TPD profile of the methanol and ethyl acetate mixture showed neither the desorption of ethyl acetate nor the formation of acetone. Thus, the results suggest that methanol adsorbs preferentially on the catalyst surface, as proposed by Hattori et al. ${ }^{2}$ for the transesterification reaction of ethyl acetate and methanol using $\mathrm{MgO}$ or $\mathrm{La}_{2} \mathrm{O}_{3}$ as catalysts, by Liu et al. using $\mathrm{SrO},{ }^{22}$ and by Liu et al. for $\mathrm{Zn}-\mathrm{Al}$ hydrotalcite ${ }^{23}$ to produce biodiesel. According to the latter, strongly basic and highly active $\mathrm{CH}_{3} \mathrm{O}$ methoxy species are formed on the catalyst surface, and they react with triglyceride molecules through the carbonyl carbon atom. This hypothesis was confirmed by Navajas et al. ${ }^{12}$ following methanol adsorption on $\mathrm{Mg} / \mathrm{Al}$ catalysts by DRIFTS analyses.

The present results suggest that EA adsorbs dissociatively in a minor quantity compared with methanol, and the acetate formed decomposes as $\mathrm{CH}_{4}$ and $\mathrm{CO}_{2}$. Ethanol and acetone formation, not observed in TPD results, could occur at a low level to be detected.

\section{Diffuse Reflectance Infrared Fourier Transform Spectroscopy - Mass Spectrometry (DRIFTSMS)}

The interaction of the probe molecules with the catalyst surface was first performed using methanol or ethyl acetate solely, and after using the mixture of the reactants. The infrared spectra after adsorption of methanol, shown in Figure 5, present bands at 2750-3000 $\mathrm{cm}^{-1}$ characteristics of the $\mathrm{C}-\mathrm{H}$ stretching mode $\left(\mathrm{V}_{\mathrm{CH} 3}\right)$ related to methoxy species and methanol molecularly adsorbed. The band near $1660 \mathrm{~cm}^{-1}$ is due to the $\mathrm{O}-\mathrm{H}$ bending mode $\left(\delta_{\mathrm{O}-\mathrm{H}}\right),{ }^{14}$ while the band at $1100 \mathrm{~cm}^{-1}$ is attributed to type I monodentate methoxy species, which is formed from the breaking of the $\mathrm{O}-\mathrm{H}$ bond of methanol. This interaction with the catalyst surface is through a bond between the oxygen atom and $\mathrm{Mg}^{2+}$ ions. According to Navajas et al. ${ }^{12}$, these species have a significant contribution to the transesterification reaction and are highly reactive. ${ }^{22}$ Recently, Hincapié and coworkers ${ }^{16}$ studied the transesterification of triacetin and methanol using DRIFTS analyses of adsorbed methanol. They have shown that methoxy type I species are correlated to the catalytic activity of mixed oxides derived from $\mathrm{Mg} / \mathrm{Al}$ hydrotalcite catalysts.

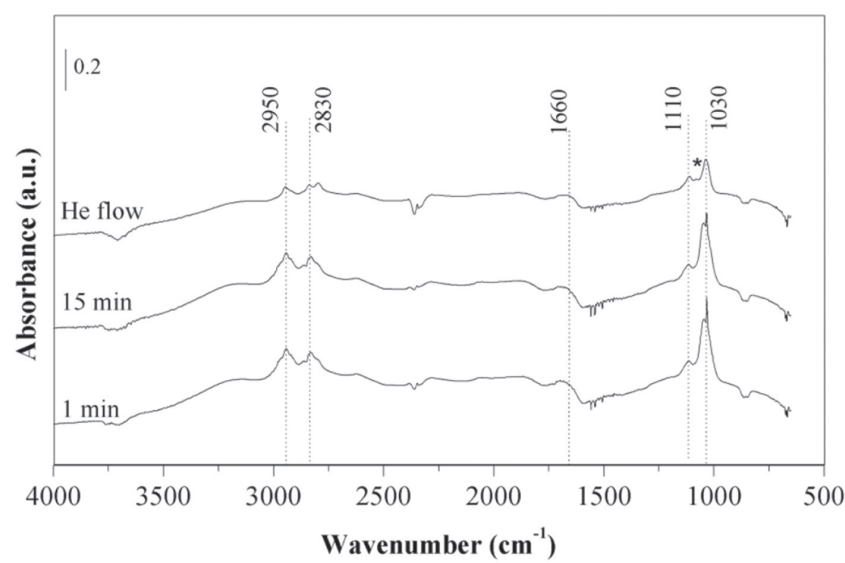

Figure 5. DRIFT spectra of the catalyst $1 \mathrm{Mg} 1 \mathrm{LaC}$ after adsorption of methanol at $30^{\circ} \mathrm{C}$ for $1 \mathrm{~min}, 15 \mathrm{~min}$, and after a flow of $\mathrm{He}$, at $30^{\circ} \mathrm{C}$ 
The band observed at $1030 \mathrm{~cm}^{-1}$ is attributed to methanol adsorbed through interaction with $\mathrm{Mg}^{2+}$ and $\mathrm{O}^{2-}$ ions on the surface without dissociation (Type $\mathrm{H}$ species). ${ }^{11,12,14,16}$ After the flow of $\mathrm{He}$, the intensity of these bands decreased due to the removal of weakly adsorbed species, and Type II methoxy species became evident as a small shoulder at $1080 \mathrm{~cm}^{-1}\left(^{*}\right)$. These species link to the surface in a bidentate form through the oxygen atom with two $\mathrm{Mg}^{2+}$ ions and can be stable even at temperatures up to $350{ }^{\circ} \mathrm{C} .{ }^{11,16}$

The spectra acquired at an increasing temperature under He flow after methanol adsorption is shown in Figure 2S, supplementary material. As the temperature increases, the spectra exhibit some modifications. At $100{ }^{\circ} \mathrm{C}$, the band at $1660 \mathrm{~cm}^{-1}$ decreased due to the water desorption. The appearance of bands in the range $1150-1550 \mathrm{~cm}^{-1}$ and at $840 \mathrm{~cm}^{-1}$, related to bi- and monodentate carbonates species, respectively, is also detected. ${ }^{24}$ The intensity of these bands increases with increasing temperature. At the temperature higher than $200^{\circ} \mathrm{C}$, the intensity of the bands at 3000 to $2600 \mathrm{~cm}^{-1}$ and $1100-1000 \mathrm{~cm}^{-1}$ decreased due to the decomposition of the methoxy species, and the band at $2345 \mathrm{~cm}^{-1}$ is associated to $\mathrm{CO}_{2}$ gas phase. The $\mathrm{CO}_{2}$ formation, which increases with temperature, could be attributed to the decomposition of methoxy and the presence of carbonate on the structure of catalyst. ${ }^{25}$

The methoxy decomposition also leads to the formation of formate species $\left(\mathrm{HCOO}^{-}\right)$, whose vibrational bands appeared around $1600 \mathrm{~cm}^{-1},{ }^{16,24}$ and $\mathrm{CO}_{2}$ adsorption $\left(2445 \mathrm{~cm}^{-1}\right)$. The increase in the intensity of the bands between $1150-1550 \mathrm{~cm}^{-1}$ and at $843 \mathrm{~cm}^{-1}$ is related to carbonate formation from the adsorption of the gaseous $\mathrm{CO}_{2}$ on the surface sample. These carbonate species are very stable at high temperatures $\left(450^{\circ} \mathrm{C}\right)$, as well as the formate species.

The gaseous phase composition during the stepwise desorption/ decomposition of methanol was determined by on-line mass spectrometry (Figure $3 \mathrm{~S}$, supplementary material). The results show that hydrogen formation begins at $100{ }^{\circ} \mathrm{C}$, reaching a maximum at $250{ }^{\circ} \mathrm{C}$ and $300{ }^{\circ} \mathrm{C}$, and could be associated with methanol dehydrogenation, which also forms formaldehyde. ${ }^{25}$ These results are following the TPD analysis for methanol adsorption (Figure 2).

The DRIFTS spectra of ethyl acetate adsorbed on $1 \mathrm{Mg} 1 \mathrm{LaC}$ are shown in Figure 6 . Adsorption at $30^{\circ} \mathrm{C}$ gives rise to bands associated with ethyl acetate weakly adsorbed. The bands are characteristic of the $\mathrm{C}-\mathrm{H}$ stretching vibrational mode $\left(2750-3000 \mathrm{~cm}^{-1}\right)$, stretching of the carbonyl group $\left(1759 \mathrm{~cm}^{-1}\right.$ and $\left.1715 \mathrm{~cm}^{-1}\right), \mathrm{CH}_{3}$ bending mode $\left(1373 \mathrm{~cm}^{-1}\right)$, and $\mathrm{C}-\mathrm{O}-\mathrm{C}$ stretching mode of the ester group $\left(1245 \mathrm{~cm}^{-1}\right)$. Some authors suggest that the bands at $1100 \mathrm{~cm}^{-1}$ and

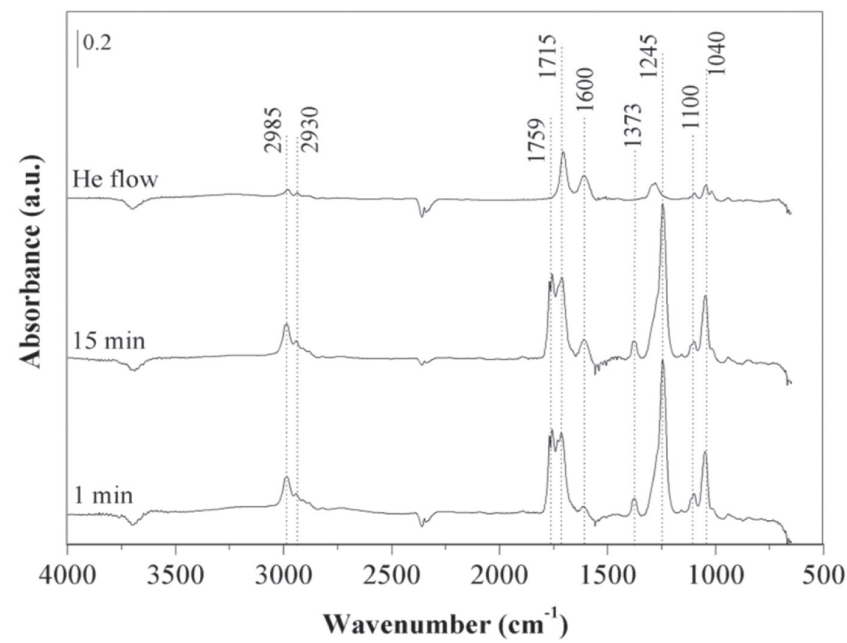

Figure 6. DRIFT spectra after adsorption of ethyl acetate on $1 \mathrm{Mg} 1 \mathrm{LaC}$ at $30{ }^{\circ} \mathrm{C}$ for $1 \mathrm{~min}, 15 \mathrm{~min}$, and after treatment of He flow
$1040 \mathrm{~cm}^{-1}$ could be due to the formation of adsorbed mono- and bidentate ethoxy species, respectively, which may be formed from the dissociative adsorption of the ethyl acetate. ${ }^{19}$

The bands at $1600 \mathrm{~cm}^{-1}$ and $940 \mathrm{~cm}^{-1}$ are due to the asymmetric stretching of the OCO bond of bidentate carbonate, ${ }^{19}$ which are formed even at low temperature. Acetate species are also formed in the region of $1590 \mathrm{~cm}^{-1}$. However, the position of the bands can vary according to the surface properties. ${ }^{21,26}$ After treatment under $\mathrm{He}$ flow, the bands at $1759 \mathrm{~cm}^{-1}\left(\mathrm{v}_{\mathrm{C}=\mathrm{O}}\right), 1373 \mathrm{~cm}^{-1}\left(\delta \mathrm{C}_{\mathrm{H} 3}\right)$, and $1245 \mathrm{~cm}^{-1}$ $\left(v_{\mathrm{COC}}\right)$ disappeared, and the intensity of the other decreased reflecting desorption of weakly adsorbed ethyl acetate.

The spectra acquired after increasing the temperature under flowing He (Figure 4S, supplementary material) showed that at temperatures higher than $100{ }^{\circ} \mathrm{C}$, the bands at about $3000-2750 \mathrm{~cm}^{-}$ 1, $1700 \mathrm{~cm}^{-1}$ and $1100 \mathrm{~cm}^{-1}$ disappeared and bands at $2352 \mathrm{~cm}^{-1}$ ( $\mathrm{CO}_{2}$ vapor phase), $2465 \mathrm{~cm}^{-1}, 1600 \mathrm{~cm}^{-1}, 1290 \mathrm{~cm}^{-1}, 1040 \mathrm{~cm}^{-1}$ and $840 \mathrm{~cm}^{-1}$ (due to species of adsorbed $\mathrm{CO}_{2}$ and acetate) increased with the temperature. In the region between $1200-1300 \mathrm{~cm}^{-1}$, it is observed an increase of the bands characteristic of carbonates due to $\mathrm{CO}_{2}$ formation, while monodentate carbonate $\left(840 \mathrm{~cm}^{-1}\right)$ appeared at $300{ }^{\circ} \mathrm{C}$.

The band at $1040 \mathrm{~cm}^{-1}$ is attributed to ethoxy species and slightly increases until $450{ }^{\circ} \mathrm{C}$, and the bidentate carbonate $\left(1600 \mathrm{~cm}^{-1}\right)$ disappeared, whereas the other species remain adsorbed. At about $1600 \mathrm{~cm}^{-1}$, there is also the contribution of acetate species $\left(1600 \mathrm{~cm}^{-1}\right.$ and $1245 \mathrm{~cm}^{-1}$ ).

Acetone formation detected at $300{ }^{\circ} \mathrm{C}$, where a band at $1750 \mathrm{~cm}^{-1}$ appears, attributed to the vibrational mode $v(\mathrm{C}=\mathrm{O})$, while the stretching mode of the bond C-C-C $\left(1216 \mathrm{~cm}^{-1}\right)$ was overlapped by the broadband at $1290 \mathrm{~cm}-1 .^{21}$

The stepwise of TPD of the ethyl acetate (Figure 3) and MS analyses (Figure 5S, supplementary material) confirm DRIFTS results since the desorption of molecular ethyl acetate $(\mathrm{m} / \mathrm{z}=61)$, and ethanol begins to occur $(\mathrm{m} / \mathrm{z}=46)$ at $100{ }^{\circ} \mathrm{C}$. The disappearance of the band due to acetate $\left(1600 \mathrm{~cm}^{-1}\right)$ together with the band at $1750 \mathrm{~cm}^{-1}$, can be attributed to acetone formation $(\mathrm{m} / \mathrm{z}=58)$, which agrees with the MS profile shown in Figure 5S (supplementary material) between 350 and $450{ }^{\circ} \mathrm{C}$, and according to infrared bands.

The adsorption of methanol and ethyl acetate mixture in the molar ratio of 1/1 produced characteristic bands of both reactants, as shown in Figure 7, which are difficult to specify to which substance belongs. Noticeable are the bands at $1600 \mathrm{~cm}^{-1}$ (bidentate carbonate), $1370 \mathrm{~cm}^{-1}$ and $1245 \mathrm{~cm}^{-1}$ (ethyl acetate), $1100 \mathrm{~cm}^{-1}$ (type I methoxy species), and $1045 \mathrm{~cm}^{-1}$ (type $\mathrm{H}$ methoxy and/or ethoxy species). The slight displacement observed can be due to an interaction between the reactants. After treatment under He flow (Figure 6S, supplementary material), bidentate carbonate, ethoxy species, and methoxy species (Type I and H) are still present on the catalyst surface. For the reaction mixture, the infrared bands of methoxy and ethoxy are not possible to distinguish one from another, but the desorption of these species can be identified through the mass profiles. As the temperature increased (Figure 6S), there was the formation of mono- and bidentate carbonates in the region of $1550-1150 \mathrm{~cm}^{-1}$. Then, at $300{ }^{\circ} \mathrm{C}$ occurred the formation of monodentate carbonate at $850 \mathrm{~cm}^{-1}$. At $400{ }^{\circ} \mathrm{C}$, bidentate carbonate $\left(1600 \mathrm{~cm}^{-1}\right)$ disappeared completely, and there was an increase in the intensity of the band at $1045 \mathrm{~cm}^{-1}$ due to ethoxy species from the dissociative adsorption of ethyl acetate. The existence of type $\mathrm{H}$ methoxy species derived from dissociative adsorption of methanol cannot be discarded once it is in the same region of ethoxy species. However, the mass profiles indicate that from this temperature and above, there is no desorption of molecules derived from the ethoxy species but those formed from methoxy species. This fact is an indication that the ethoxy species 


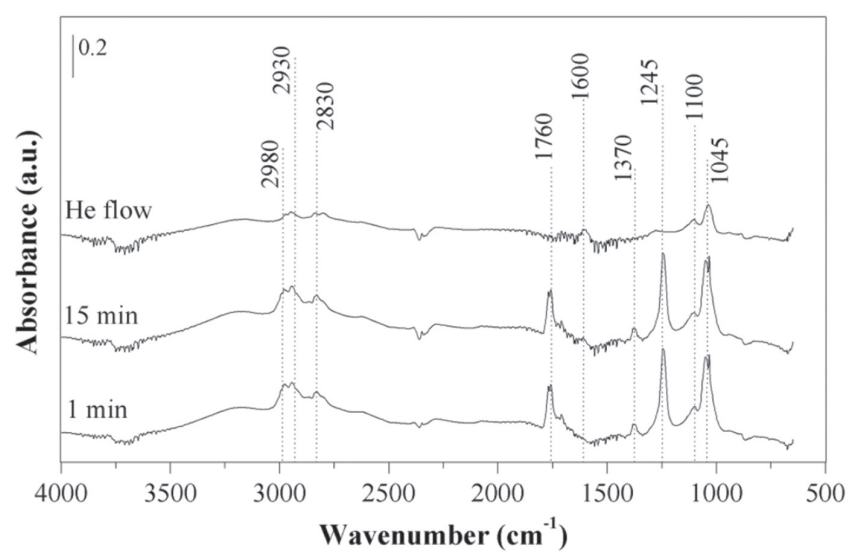

Figure 7. DRIFT spectra of the catalysts $1 \mathrm{Mg} 1 \mathrm{LaC}$ after adsorption of the mixture, methanol and ethyl acetate $1: 1$, at $30^{\circ} \mathrm{C}$, during $1 \mathrm{~min}, 15 \mathrm{~min}$, and after He flows

remain adsorbed on the catalyst, while the methoxy species desorbed continuously until the end of the experiment.

Mass spectrometry profiles (Figure 7S, supplementary material) show that methanol and traces of ethyl acetate weakly adsorbed desorbs together with ethanol formed from the ethoxy species adsorbed. Hydrogen desorption below $400{ }^{\circ} \mathrm{C}$ was due to the decomposition of ethyl acetate and methanol. Further, methoxy and acetate species adsorbed also form $\mathrm{CO}_{2}, \mathrm{H}_{2}$, and methane at temperatures of $400{ }^{\circ} \mathrm{C}$. A small quantity of acetone was formed via oxidation reaction of ethoxy species that remained adsorbed at 450 and $500^{\circ} \mathrm{C}$

Therefore, DRIFT spectra confirmed that methanol adsorbs preferentially on the basic sites of the $1 \mathrm{Mg} 1 \mathrm{LaC}$ catalyst since the adsorbed species detected are mainly those formed from methanol adsorption. However, ethoxy species were also detected in a minor intensity and are characteristics of EA adsorbed in a dissociative form.

Besides ethanol, traces of acetone and methane also occurred. Acetate formation also occurs and can produce $\mathrm{CH}_{4}$ and $\mathrm{CO}_{2}$, as discussed above, for TPD analyses and confirmed by DRIFT spectra.

According to the literature, alkoxides species formed from alcohol adsorption play an essential role in the transesterification reaction catalyzed by basic solids. The Eley-Rideal mechanism is the most accepted model for the transesterification reaction. Accordingly to this mechanism, alcohol adsorbs on a surface basic site. It forms an adsorbed alkoxide that attacks a carbonyl carbon of an ester in the liquid phase, forming a tetrahedral intermediate, which is then rearranged to produce another ester. ${ }^{1,22,27-31}$ Besides, other mechanisms are suggested, as the alcohol and ester adsorbing on surface neighboring basic sites forming an intermediate; ${ }^{2,32}$ or the ester adsorption followed by the reaction with the alcohol in a liquid phase,,$^{33}$ and yet, another mechanism in which the ester interacts with the alcohol adsorbed on the surface before its reaction with a molecule of the alcohol in the liquid phase. However, these mechanisms were proposed based on kinetic studies or product distribution observed in catalytic tests ${ }^{2,24}$ without the support of spectroscopic techniques.

On the other hand, Phung et al. ${ }^{21,26}$ studied the nature of EA interaction with the catalyst surface by infrared spectroscopy. First, conversions of ethyl acetate and acetic acid on alumina-based catalysts as a model to triglyceride reactions, and infrared results showed that the ester was activated by adsorbing on the Lewis sites of alumina by carbonyl oxygen. ${ }^{21}$ In the second, the authors evaluated the conversion of EA over faujasite zeolites to obtain highly selective catalysts for liquid fuels from vegetable oils. ${ }^{26}$ The EA adsorption occurs via the lone pair of the carbonyl oxygen on the electron-withdrawing site.
The sample with the absence of Lewis sites $(\mathrm{NaX})$ presented low conversion, which confirmed the way of EA adsorption.

These studies ${ }^{2,21,26,27}$ were important to make a correspondence with our results and obtain an understanding of methanol and EA interaction with the $1 \mathrm{Mg} 1 \mathrm{LaC}$ catalyst surface. Therefore, considering the TPD and DRIFTS-MS results, we summarize hereafter the intermediate species reactions and formation of the products, which could drive to propose a surface intermediates reaction for $\mathrm{Mg}$-La based catalysts.

Thus, methanol adsorbs forming methoxy species (infrared bands at $1100 \mathrm{~cm}^{-1}$ and $1045 \mathrm{~cm}^{-1}$ ) on the catalyst surface as:

$$
\mathrm{CH}_{3} \mathrm{O}^{-} \text {ads }\left(\mathrm{M}^{+}\right)_{\mathrm{s}}+\mathrm{H}_{(\text {ads })}^{+} \mathrm{O}_{(\mathrm{s})}^{-} \rightarrow \mathrm{CH}_{4}+2 \mathrm{O}_{(\mathrm{s})}^{-}
$$

EA also adsorbs on the surface through the oxygen of carbonyl groups forming ethoxy $\left(1045 \mathrm{~cm}^{-1}\right)$ and acetate species $\left(1600 \mathrm{~cm}^{-1}\right.$ and $1245 \mathrm{~cm}^{-1}$ ):

$\mathrm{H}_{3} \mathrm{C}-\mathrm{CH}_{2}-\mathrm{OO} \mathrm{C}^{+}-\mathrm{CH}_{3 \text { (ads) }}\left(\mathrm{M}^{+}\right)_{\mathrm{s}} \rightarrow \mathrm{H}_{3} \mathrm{C}_{-}-\mathrm{CH}_{2}-\mathrm{O}^{-}{ }_{\text {(ads) }}+\mathrm{H}_{3} \mathrm{C}-\mathrm{COO}^{-}{ }_{\text {(ads) }}$

The acetate decomposition can form methane (MS fragment $\mathrm{m} / \mathrm{z}=14$ ) and $\mathrm{CO}_{2}$ gas phase (IR band at $2345 \mathrm{~cm}^{-1}$ ); while ethoxy desorbs as ethanol (MS fragment $\mathrm{m} / \mathrm{z}=46$ ).

$$
\begin{gathered}
\mathrm{H}_{3} \mathrm{C}_{-} \mathrm{COO}^{-}{ }_{\text {(ads) }}\left(\mathrm{M}^{+}\right)_{\mathrm{s}}+\mathrm{H}^{+}{ }_{(\mathrm{ads})} \mathrm{O}^{-}{ }_{(\mathrm{s})} \rightarrow \mathrm{CO}_{2(\mathrm{~g})}+\mathrm{CH}_{4(\mathrm{~g})} \\
\mathrm{H}_{3} \mathrm{C}-\mathrm{CH}_{2}-\mathrm{O}^{-}{ }_{\text {(ads) }}\left(\mathrm{M}^{+}\right)_{\mathrm{s}}+\mathrm{H}^{+}{ }_{(\mathrm{ads})} \mathrm{O}^{-}{ }_{(\mathrm{s})} \rightarrow \mathrm{H}_{3} \mathrm{C}-\mathrm{CH}_{2}-\mathrm{OH}+\mathrm{O}^{-}{ }_{(\mathrm{s})}
\end{gathered}
$$

Also, the acetate species form acetone (IR bands at $1750 \mathrm{~cm}^{-1}$ and $1216 \mathrm{~cm}^{-1}$; MS fragment $\mathrm{m} / \mathrm{z}=58$ ).

$$
2 \mathrm{CH}_{3} \mathrm{COO}^{-}{ }_{\text {ads }} \rightarrow \mathrm{CH}_{3} \mathrm{COCH}_{3(\mathrm{~g})}+\mathrm{CO}_{2(\mathrm{~g})}+\mathrm{O}_{(\mathrm{s})}^{-}
$$

Moreover, methanol and EA should form a tetrahedral intermediate, as suggested by Hatori et al. ${ }^{2}$ :

$\mathrm{H}_{3} \mathrm{C}-\mathrm{CH}_{2}-\mathrm{OO}^{-} \mathrm{C}^{+}-\mathrm{CH}_{3}(\mathrm{ads})\left(\mathrm{M}^{+}\right)_{\mathrm{s}}+\mathrm{CH}_{3} \mathrm{O}_{a d s}^{-}\left(\mathrm{M}^{+}\right)_{\mathrm{s}}+{H^{+}}_{(\mathrm{ads})}+\mathrm{O}^{-}{ }_{(\mathrm{s})} \rightarrow$ $\mathrm{H}_{3} \mathrm{C}-\mathrm{CH}_{2}-\mathrm{OH}_{(\mathrm{g})}+\boldsymbol{H}_{3} \mathrm{C}-\mathrm{OO}-\mathrm{C}-\mathrm{CH}_{3(\mathrm{~g})}$

Notwithstanding, our results indicated that in the simultaneous feeding of $\mathrm{MeOH}$ and EA, the preferential adsorption of $\mathrm{MeOH}$ was observed. Thus, they confirm that the Eley-Rideal mechanism involving the adsorbed alcohol should be the principal reaction route for transesterification reactions as proposed by other studies, ${ }^{27,30}$ however, the contribution of the reaction between the alcohol molecule and the ester adsorbed on neighbor sites cannot be discharged.

\section{CONCLUSIONS}

To better understand the transesterification reaction catalyzed by the Mg-La catalyst, surface studies using methanol and ethyl acetate as probe molecules were carried out employing TPD and DRIFTS-MS. TPD analyses showed that methanol adsorbed on $1 \mathrm{Mg} 1 \mathrm{LaC}$ catalyst formed formaldehyde and hydrogen via dehydrogenation reaction, whereas adsorbed ethyl acetate produced ethanol and acetone. DRIFTS analyses confirmed that the adsorption of ethyl acetate produced acetate and ethoxy adsorbed species, which produced ethanol and acetone via oxidation reaction, whereas from adsorbed methanol, type II methoxy species, produced formate, and hydrogen.

DRIFTS-MS experiments allowed not only the identification of the intermediate species adsorbed on the catalyst surface but also the gas-phase products formed simultaneously. Thus, for the studied catalyst, it was possible to confirm the preferential adsorption of 
methanol and that EA adsorbs on Mg-La surface in a dissociative form. Also, the coupling of MS to DRIFTS allowed identifying small quantities of gas-phase formed during the heating step, like methane. Surface intermediate's reactions were proposed, which confirmed that the Eley-Rideal type mechanism is the predominant on the studied catalyst surface.

\section{SUPPLEMENTARY MATERIAL}

Results concerning TPD profiles of $\mathrm{CO}_{2}$ and $\mathrm{H}_{2} \mathrm{O}$ after EA adsorption (Figure 1S), DRIFTS-MS after desorption of methanol (Figures 2S-3S), ethyl acetate (Figures 4S-5S), and the mixture of methanol with ethyl acetate (Figures 6S-7S), are available in http://quimicanova.sbq.org.br, as a PDF profile and free downloading.

\section{ACKNOWLEDGMENTS}

The authors thank NUCAT laboratory (PEQ/COPPE/UFRJ) for the TPD and DRIFTSMS analyses.

This study was financed in part by the Coordenação de Aperfeiçoamento de Pessoal de Nível Superior - Brazil (CAPES) - Finance Code 001.

\section{REFERENCES}

1. Dossin, T. F.; Reyniers, M. F.; Berger, R. J.; Marin, G. B.; Appl. Catal., $B$ 2006, 67, 136.

2. Hattori, H.; Shima, M.; Kabashima, H.; Stud. Surf. Sci. Catal. 2000, 130, 3507.

3. Santório, R.; Veloso, C. de O.; Henriques, C. A.; J. Mol. Catal. A: Chem. 2016, 422, 234

4. Antunes, W. M.; Veloso, C. de O.; Henriques, C. A.; Catal. Today 2008, 133-135, 548

5. Islam, A.; Taufiq-Yap, Y. H.; Chu, C. M.; Chan, E. S.; Ravindra, P.; Proc. Saf. Environ. Prot. 2013, 91, 131.

6. Zeng, H.; Feng, Z.; Deng, X.; Li, Y.; Fuel 2008, 87, 3071.

7. Navajas, A.; Campo, I.; Arzamendi, G.; Hernández, W. Y.; Bobadilla, L. F.; Centeno, M. A.; Odriozola, J. A.; Gandía, L. M.; Appl. Catal., B 2010, 100, 299.

8. Desmartin-Chomel, A.; Hamad, B.; Palomeque, J.; Essayem, N.; Bergeret, G.; Figueras, F.; Catal. Today 2010, 152, 110.
9. Babu, N. S.; Sree, R.; Prasad, P. S. S.; Lingaiah, N.; Energy Fuels 2008, $22,1965$.

10. Chuayplod, P.; Trakarnpruk, W.; Ind. Eng. Chem. Res. 2009, 48, 4177.

11. Bensitel, M.; Saur, O.; Lavalley, J. C.; Mater. Chem. Phys. 1991, 28, 309.

12. Navajas, A.; Arzamendi, G.; Romero-Sarria, F.; Centeno, M. A.; Odriozola, J. A.; Gandía, L. M.; Catal. Commun. 2012, 17, 189.

13. Rudberg, J.; Foster, M.; J. Phys. Chem. B 2004, 108, 18311.

14. Moulin, B.; Oliviero, L.; Bazin, P.; Daturi, M.; Costentin, G.; Maugé, F.; Phys. Chem. Chem. Phys. 2011, 13, 10797.

15. Chizallet, C.; Bailly, M. L.; Costentin, G.; Lauron-Pernot, H.; Krafft, J. M.; Bazin, P.; Saussey, J.; Che, M.; Catal. Today 2006, 116, 196.

16. Hincapié, G.; López, D.; Moreno, A.; Catal. Today 2018, 302, 277.

17. Simanjuntak, F. S. H.; Tanda, V.; Soo, C.; Sung, B.; Jin, Y.; Lee, H.; Chem. Eng. Sci. 2013, 94, 265.

18. César, D. V.; Robertson, R. F.; Resende, N. S.; Catal. Today 2008, 133-135, 136.

19. Yee, A.; Morrison, S. J.; Idriss, H.; J. Catal. 1999, 186, 279.

20. Idriss, H.; Seebauer, E. G.; J. Mol. Catal. A: Chem. 2000, 152, 201.

21. Phung, T. K.; Casazza, A. A.; Aliakbarian, B.; Finocchio, E.; Perego, P.; Busca, G.; Chem. Eng. J. 2013, 215-216, 838.

22. Liu, X.; He, H.; Wang, Y.; Zhu, S.; Catal. Commun. 2007, 8, 1107.

23. Liu, Q.; Wang, B.; Wang, C.; Tian, Z.; Qu, W.; Ma, H.; Xu, R.; Green Chem. 2014, 16, 2604

24. Busca, G.; Lorenzelli, V.; Mater. Chem. 1982, 7, 89.

25. Li, C. L.; Lin, Y. C.; Catal. Letters 2010, 140, 69.

26. Phung, T. K.; Carnasciali, M. M.; Finocchio, E.; Busca, G.; Appl. Catal., A 2014, 470, 72.

27. Dossin, T. F.; Reyniers, M. F.; Marin, G. B. ; Appl. Catal., B 2006, 62, 35.

28. Veiga, P. M.; Luna, A. S.; de Figueiredo Portilho, M.; de Oliveira Veloso, C.; Henriques, C. A.; Energy 2014, 75, 453.

29. Yan, S.; Salley, S. O.; Simon Ng, K. Y.; Appl. Catal., A 2009, 353, 203.

30. Liu, X.; He, H.; Wang, Y.; Zhu, S.; Piao, X.; Fuel 2008, 87, 216.

31. Chantrasa, A.; Phlernjai, N.; Goodwin, J. G.; Chem. Eng. J. 2011, 168, 333.

32. Yan, S.; Kim, M.; Salley, S. O.; Ng, K. Y. S.; Appl. Catal., A 2009, 360, 163.

33. Pal, N.; Paul, M.; Bhaumik, A.; J. Solid State Chem. 2011, 184, 1805. 